\title{
Onomatopoeia and Regular Sound Changes
}

\author{
Maria A. Flaksman* \\ Saint Petersburg Electrotechnical University «LETI» \\ St. Petersburg, Russian Federation
}

Received 05.10.2018, received in revised form 06.11.2018, accepted 20.11.2018

\begin{abstract}
The article deals with the problem of diachronic development of onomatopoeic lexicon and discusses how regular sound changes affect imitative words. The classification according to the degrees of the impact of regular sound changes is devised and applied to the bulk of English sound-imitative words.

The aim of the article is to establish which regular sound changes of the English language had the most detrimental effect. In order to achieve this aim, all major English regular sound changes are classified into phonosemantically significant and phonosemantically insignificant. This classification is based on the use of methods of historical-comparative linguistics and etymological analysis.

The main result is the revelation of the fact that not all regular sound changes are equally detrimental to the iconic lexicon of a language. They are only so if: 1) touch upon salient, meaning-bearing phonemes of an iconic word; 2) change the original phonotype of a phoneme; and 3) take place when the word still retains its original sound-meaning coherence. The devised classification is potentially universal and applicable to the onomatopoeic lexicons of related and unrelated languages.
\end{abstract}

Keywords: onomatopoeia, regular sound changes, diachronic linguistics, iconicity, sound symbolism, etymology, phonosemantics.

Research area: philology.

Citation: Flaksman, M.A. (2018 online). Onomatopoeia and Regular Sound Changes. J. Sib. Fed. Univ. Humanit. soc. sci., 2022 15(10), 1508-1515. DOI: 10.17516/1997-1370-0351

(C) Siberian Federal University. All rights reserved

* Corresponding author E-mail address: mariaflax@gmail.com 


\title{
Звукоподражания и регулярные фонетические изменения
}

\author{
М.А. Флаксман \\ Санкт-Петербургский государственный \\ электротехнический университет «ЛЭТИ» \\ Российская Федерачия, Санкт-Петербург
}

\begin{abstract}
Аннотация. Статья посвящена вопросам изучения звукоподражательной лексики в диахронии и рассматривает, какое влияние оказывают регулярные фонетические изменения на слова с иконической связью между фонетическим обликом и денотатом. В работе обсуждается предложенная ранее классификация регулярных фонетических изменений на фоносемантически значимые и фоносемантически незначимые, дается обзор основных фонетических изменений английского языка. В исследовании применяются методы сравнительно-исторического языкознания и этимологического анализа. В результате проведенной работы удалось выделить группы фонем, являющиеся ключевыми для основных классов английских ономатопов, а также потенциальные группы фонемных сочетаний, изменение которых в будущем может повлечь за собой утрату иконической, подражательной связи, изначально присущей любому звукоизобразительному слову. Одним из наиболее значимых результатов исследования является выделение критериев фоносемантически значимых регулярных изменений. Чтобы считаться таковым, изменение должно: 1) затрагивать центральные, смыслонесущие фонемы звукоизобразительного слова; 2) выводить фонемы за рамки фонотипа; 3) происходить в слове, еще не утратившем первоначальную семантику, связанную со звукообозначением. Предложенная модель классификации регулярных фонетических изменений потенциально применима к языкам других групп и семей.
\end{abstract}

Ключевые слова: звукоподражания, ономатопея, регулярные фонетические изменения, диахрония, иконичность, звукосимволизм, этимология, фоносемантика.

Научная специальность: 10.00 .00 - филологические науки.

\section{Introduction}

Onomatopoeia has always been enigmatic to the researchers of language. It creates a link between the seemingly isolated universe of human language and the rest of the world in its diverse manifestations.

Even Ferdinand de Saussure, one of the founders of modern linguistics admitted (Saussure, 2006: 81) that onomatopoeic words were a hindrance to the otherwise perfect theory of the arbitrariness of the linguistic sign. Such words considerably 'spoiled' the impeccable picture where form and meaning existed independently of each other and nomination was a mere convention.

Ever since the appearance of Saussure's Cours de linguistique générale onomatopoeia has been an 'unwanted child' of structuralism, and later of the domineering theory of generative grammar. The notion of existence of nonconventional, natural link between sound and meaning simply doesn't fit into these theories.

These notions result in the marginalization of onomatopoeic words and create a view that they are nothing but linguistic oddities, peculiar items in the Cabinet of Curiosities of modern linguistics.

In the present article I challenge this view and aim to show how evolutionary processes in the language obscure originally onomatopoeic words, making their originally imitative nature invisible for the present-day researchers. 


\section{Theoretical framework}

It is impossible to speak about onomatopoeia without mentioning iconicity. 'Iconicity' is a term belonging to the realm of semiotics. It describes a relation between sign and its object as a relation of similarity.

The semiotic triad image - icon - symbol was first introduced by Charles Sanders Peirce (Peirce, 2018) and later applied to the human language. The vast majority of the present-day words are symbols (arbitrary relation between sign and its object, or word form and its denotatum); and onomatopoeic words - which are a minority - are linguistic icons.

Studies of linguistic iconism now encompass general theoretical problems of linguistic sign (Jakobson, Waugh, 1979; Jespersen, 1933; Wescott, 1980), studies on reduplication (Rozhanskii, 2011; Moreno Cabrera, 2017), sound symbolism (Abelin, 1999; Hinton et al., 1994; Kuzmich, 1993; Marchand, 1959; Slonitskaia, 1987; Bartens, 2000), onomatopoeia (Voeltz et al., 2001; Voronin, 1998; Lapkina, 1979; Shliakhova, 1991; Veldi, 1988) and other related issues (Anderson, 1998; Voronin, 2005, Voronin, 2006; Gazov-Ginzberg, 1965; Kankiia, 1988; Dingemanse and Akita, 2017).

Over the past decades appeared several specialized dictionaries of onomatopoeic words (Taylor, 2007; Flaksman, 2016; Written Sound, 2018; Iconicity Atlas, 2018) and the studies of onomatopoeic lexicons in different languages are gaining ground.

On the whole, the growing bulk of data from languages of different language families is paving the way for the re-examination of the role played by iconicity in the human language.

\section{Problem statement}

Despite the continuous appearance of books and articles on onomatopoeia in various languages (see the paragraph above), most of these works deal with the synchronous level of language, rarely taking into account diachronic problems of onomatopoeia (outstanding exceptions to this tendency see - Brodovich, 2008; Joseph, 1997; Liberman, 2010; Malkiel, 1990). Yet diachronic approach gives a new insight into the nature of onomatopoeia.
In the present paper we continue the discussion we started in (Flaksman, 2015; Flaksman, 2017) and describe how regular sound changes affect English onomatopoeic word, focusing on the five main sub-classes of imitative words - instants, continuants, frequentatives, instants-continuants and frequentatives-instantscontinuants (see Voronin, 2006: 39).

\section{Methods}

Methods applied in the present research are historical-comparative method, etymological analysis and the method of phonosemantic analysis (introduced in Voronin, 2006: 87).

The method of phonosemantic analysis is a combination of etymological investigation and typological comparison which takes into account such salient iconic traits as reduplication (e. g. E. clap-clap), syllable-lengthening (E. baa-a-a), expressive ablaut (e. g. E. tick-tock, flip-flop), metathesis, expressive gemination, etc. (Voronin, 2006, op. cit.: 91).

The method is used when there is a need to establish or verify the iconic origin of a word, and, therefore, in the present study is used supplementary.

\section{Stanislav Voronin's classification of onomatopoeic words}

For the purposes of the present article I briefly describe the classification of onomatopoeic words designed by S. V. Voronin (Voronin, 2006). His classification is based upon a comparison of the oscillogram recordings of speech sounds and the sounds of the natural world.

According to Voronin (Voronin, 2006, op. cit.: 39), onomatopoeic words are classified into five major categories: three pure - instants, continuants, frequentatives and two mixed instants-continuants and frequentativesinstants-continuants. Here are the main characteristics of these sub-classes of onomatopoeic words:

- Instants imitate pulse-like natural sounds via usage of plosives;

- Continuants imitate prolonged tones or noises via usage of 1) (long) vowels or 2) fricatives and/or sibilants;

- Frequentatives imitate vibratory dissonance-like sounds via trills; 
- Instants-continuants imitate sounds which combine the traits of pulses and tones;

- Frequentatives-instants-continuants

(FIC) designate sounds combining the traits of dissonances, pulses and tones.

Thus, examples of instants in English will be tap, tick, clap, pip. Here the plosive nature of $/ \mathrm{b} /$, $/ \mathrm{p} /$ acoustically reflects intense natural sounds of short duration. To tonal continuants belong hoot and peep; to noise continuants - sizzle and hiss. To the sub-class of frequentatives belong purr and chirr (historically /pvr/ and / $/ \mathrm{fr} /$ /). Examples of instants-continuants are plump, clash, flap and slump; of frequentatives-instants-continuants crash, rush and scream.

The given division of onomatopoeic words into these cathegories is based on the comparison of acoustic charachteristics of the phonemes (as they are pronounced in speech) with the achoustic charasteristics of natural sounds.

\section{Phonosemantically significant regular sound changes}

The nature of sound changes is very elusive. Small changes like grains of sand in an hour-glass slowly make a huge difference. Therefore, one can't draw a strict line and say that yesterday the word was more iconic than today because a sound change has happened overnight.

In addition to that, not all regular sound changes of a language are equally 'dangerous' for imitative words.

For example, in the word tap 'a light blow or knock' two plosives iconically denote abrupt sounds they have acoustic similarity to, and the vowel between them is positioned to avoid forming a vowelless syllable *tp. Therefore, any potential sound change affecting this vowel is less 'drastic' from the standpoint of phonosemantics than any change touching upon either of the consonants.

In order to differentiate the regular sound changes I proposed to classify them into phonosemantically significant and phonosemantically insignificant (Flaksman, 2015: 93).

To be considered phonosemantically significant a sound change should:

- touch upon salient, meaning-bearing phonemes of an iconic word;
- change the original phonotype of a phoneme (e. g. plosives);

- take place when the word still retains its original sound-meaning link.

When and only when these three conditions, as explained below, are fulfilled, a sound change can be pronounced phonosemantically significant.

\section{Condition 1}

In order to establish which of the phonemes constituting an imitative word bear the specific, mimetic meaning, one should consult either S. V. Voronin's universal classification of onomatopoeic words or the basic description of iconic lexemes, like we did with tap.

In case the sound change occurs in the words of corresponding iconic classes and touches upon respective phonemes it may be regarded as phonosemantically significant (if conditions 2 and 3 are fulfilled as well).

For instance, the vocalization of $/ \mathrm{r} /$ which started in the $16^{\text {th }}$ century in the British English and touched upon snore (an imitative word belonging to the FIC class) made /r/ (the meaningbearing phoneme) lose its acoustic quality necessary for denoting a coarse vibrating sound heard when someone breathes through nose and mouth while asleep. At present, snore is pronounced / sno:/ and its form is far less capable for miming its meaning. Note, that in other languages the notion to snore is conveyed through related and unrelated words, containing R of one quality or other (Russ. xpanemb /xrapet $\mathrm{i} /$, Germ. schnarchen, Sp. roncar, It. ronfare, russare).

The meaning-bearing phonemes for different classes of imitative words are listed above with special reference to English (see Table 1).

\section{Condition 2}

Not all sound changes can have a significant impact on iconic words even if examined separately, disregarding Condition 1. For instance, the $\mathrm{a}>\mathfrak{x}$ change (acknowledged by most of the linguists) cannot be phonosemantically significant, as acoustic characteristics of both sounds are more or less similar (both vowels are lax, low and front).

There is a want of appropriate examples in the history of the English language, as /æ/ sound 
Table 1. Meaning-Bearing Phonemes According to Subclasses of Onomatopoeic Words (In English)

\begin{tabular}{|c|c|c|c|c|}
\hline \multicolumn{5}{|c|}{ Onomatopoeic Words } \\
\hline \multicolumn{2}{|c|}{ Phonosemantic Class } & $\begin{array}{c}\text { Phonotypes, } \\
\text { meaning-bearing } \\
\text { phonemes belong to }\end{array}$ & $\begin{array}{c}\text { Meaning-bearing phonemes } \\
\text { in English }\end{array}$ & Examples \\
\hline \multicolumn{2}{|l|}{ Instants } & $\begin{array}{l}\text { plosives } \\
\text { and affricates }\end{array}$ & $\begin{array}{l}/ \mathrm{p} /, / \mathrm{b} /, / \mathrm{t} /, / \mathrm{d} /, / \mathrm{k} /, / \mathrm{g} / \\
\text { and } / \mathrm{tg} /, / \mathrm{d} /\end{array}$ & tap, knock, blip \\
\hline \multirow[t]{2}{*}{ Continuants } & Pure Tones & (long/tense) vowels & $\begin{array}{l}\text { /u:/, /a:/, /i:/, /o:/ + historical long } \\
\text { vowels and modern diphthongs }\end{array}$ & hoot, screech \\
\hline & Pure Noises & sibilants, fricatives & 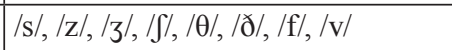 & fizz, flash \\
\hline \multicolumn{2}{|c|}{ Frequentatives } & $\mathrm{R}$ (vibr. or other) & $/ \mathrm{r} /$ & historically chirr \\
\hline \multicolumn{2}{|c|}{\begin{tabular}{|l|} 
Instants-Continuants \\
\end{tabular}} & $\begin{array}{l}\text { plosives }+ \text { sibi- } \\
\text { lants, fricatives }\end{array}$ & $\begin{array}{l}/ \mathrm{p} /, / \mathrm{b} /, / \mathrm{t} /, / \mathrm{d} /, / \mathrm{k} /, / \mathrm{g} /+/ \mathrm{s} /, \\
/ \mathrm{z} /, / \mathrm{z} /, / \mathrm{J} /, / \theta /, / \mathrm{d} /, / \mathrm{f} /, / \mathrm{v} /\end{array}$ & $\begin{array}{l}\text { flap, thump, } \\
\text { clash }\end{array}$ \\
\hline \multicolumn{2}{|l|}{ FIC } & $\begin{array}{l}\text { plosives }+ \text { sibilants, } \\
\text { fricatives }+\mathrm{R}\end{array}$ & $\begin{array}{l}/ \mathrm{p} /, / \mathrm{b} /, / \mathrm{t} /, / \mathrm{d} /, / \mathrm{k} /, / \mathrm{g} /+/ \mathrm{s} /, / \mathrm{z} /, \\
/ \mathrm{\zeta} /, / \mathrm{s} /, / \theta /, / \mathrm{d} /, / \mathrm{f} /, / \mathrm{v} /+/ \mathrm{r} /\end{array}$ & thrum \\
\hline
\end{tabular}

does not happen to be a chief 'carrier' of the iconic meaning in any types of imitative words (see Table 1), and therefore Condition 2 cannot be fulfilled while Condition 1 is fulfilled. The a $>\mathfrak{x}$ sound change occurring in such imitative words like flap and brattle, is not phonosemantically significant because it doesn't touch upon meaningbearing phonemes (in this case phonesthemes) $\mathrm{br}$ and $f$ - (Condition 1 is not fulfilled) and because it doesn't change the phonotype of concerned phoneme (Condition 2 is not fulfilled as well).

\section{Condition 3}

A sound change cannot be phonosemantically significant if it occurs after the loss of the word's original meaning. In this case, the sound-meaning correlation is already destroyed and the word is no longer iconic. The only harm such sound change can make is to complicate the etymologist's work, as the task of unraveling the iconic origins becomes more and more difficult with every sound change.

Let's consider, for example, the $v>_{\Lambda}$ change happening in the $17^{\text {th }}$ century in the word lunch, originally a denotation of the chewing motion accompanied by a munching sound. The sound change cannot bear any effect whatsoever on the sound-meaning correlation of the word - by the time the sound changed started the word had already lost its original sound-related meaning and the new one - 'a type of meal' - had but arbitrary connection to its form.

\section{Some remarks on the classification}

It should be noted that one and the same regular sound change can be phonosemantically significant for one word while not so for other. For instance, $v>\Lambda$ sound change that occurred in the English language in the $17^{\text {th }}$ century was phonosemantically significant for bubble, a sound symbolic word, denoting a round object, as it has broken the labial cluster /bob-/, that iconically copied the articulation (for the discussion of iconicity in denotation of round objects - see Slonitskaia, 1987). The same regular sound change ( $v>\Lambda$ in the $17^{\text {th }}$ century) was not phonosemantically significant for such word as scrub, another FIC. The main meaning-bearing phoneme for words of such type is $/ \mathrm{r} /$, and the sound change affecting $/ v /$ has no effect on the iconic sound-sense correlation 'a harsh, scraping sound': /r/'s acoustic characteristics.

\section{Phonosemantically significant regular sound changes of the English language}

The research has shown that the phonosemantically significant sound changes of the British English are (on condition that they have taken place not after the loss of the original meaning):

- $r$-vocalization in the $16^{\text {th }}$ century - for all frequentatives (as in chirr where $/ \mathrm{r}$ / conveyed a shrill trilled sound, missing in modern pronunciation $/ \mathrm{t} 3 \mathrm{3}: /$ ); for all FIC groups (as in snore - see above); for for individual iconic words where the quality of preceding vowel changes significantly 
as well (as in squirm, where the vowel's pitch lowers in the course if r-vocalization);

- Great Vowel Shift (predominantly i:>ar and $u$ : $>$ av changes) - for continuants (pure tones) where change of vowel quality or its diphthongization are phonosemantically significant (as in howl (ME /hu: lən/) where u:>av change transformed /u:/ sound which is most suitable for denoting a low-frequency wail characteristic of a wolf or a hound);

- u>a change in the $17^{\text {th }}$ century - for several onomatopoeic words (e. g. bumble, fuzz, mutter);

- other regular sound changes occurring rarely in individual iconic words - e. g. the loss of initial $/ \mathrm{k} /$ in knock is phonosemantically significant because the sound belongs to the phonotype 'plosives' and the word is an instant according to the Voronin's classification.

Thus, regular sound changes gradually obscure the iconic sound-sense link between originally existing in every onomatopoeic word, making it invisible to the present day investigation.

\section{Conclusions and discussion}

Iconicity loss is a gradual process, invisible to the eye, but evident from the diachronic perspective. Every new generation of speakers alters the sound shape of onomatopoeic words unconsciously using patterns of sound change existing in their language. Accumulation of such changes leads to the weakening of the soundsense link which, on the first place, makes onomatopoeic words iconic, that is, easily recognizable as bright, vivid allusions to the sounds of nature. Some regular sound changes forcibly accelerate the process of iconicity loss, as they touch upon the most salient phonemes used in sound imitation.

In order to outline these changes in the history of a particular language one should, first of all, turn to the study of the structures of onomatopoeic words of this language. Whereas patterns of imitation show a striking similarity across languages of different families, varying phonemic inventories and rules of phonotactics add to accumulation of language specific traits in onomatopoeia. Upon establishing the 'key' phonemes in the onomatopoeic words' structure one can turn to the regular sound changes and see whether these changes alter the phonotypes of the phonemes in question and whether they take place before the word has lost its original meaning via metaphor and metonymy. After these procedures one can decide whether the changes have been phonosemantically significant or not.

The proposed approach to the examination of regular sound changes sheds light to the hidden history of onomatopoeic words and reveals that the role they play in the obscuring traces of iconicity in the language should not be underestimated.

\section{References}

Abelin, Å. (1999). Studies in Sound Symbolism. Göteborg, Göteborg University Press, 327 p.

Dingemanse, M., Akita, K. (2017). An inverse relation between expressiveness and grammatical integration: on the morphosyntactic typology of ideophones, with special reference to Japanese. In Journal of Linguistics, 53(3), 501-532.

Anderson, E. (1998). A Grammar of Iconism. London, Associated University Press, 399 p.

Bartens, A. (2000). Ideophones and Sound Symbolism in Atlantic Creoles. Helsinki, Gummerus Printing Saarjärvi, 198 p.

Brodovich, O.I. (2008). Zvukoizobrazitel'nost' i zvukovye zakony [Iconicity and Sound Changes]. In Iazyk-Soznanie-Kul'tura-Sotsium. Saratov, Nauka, 485-489.

Flaksman, M.A. (2015). Diakhronicheskoie razvitie zvukoizobrazitel'noi leksiki angliiskogo iazyka [Diachronic Development of English Iconic Vocabulary]. Cand. Diss. Phil., St. Petersburg, University of St. Petersburg, 580 p.

Flaksman, M.A. (2015). Zvukoizobrazitel'naia leksika angliiskogo iazyka $v$ sinkhronii i diakhronii [English Iconic Vocabulary in Synchrony and Diachrony]. St. Petersburg, SPbSEU 'LETI' University Press, 199 p. 
Flaksman, M.A. (2016). Slovar' angliiskoi zvukoizobrazitel'noi leksiki v diakhronicheskom osveshchenii [A Dictionary of English Iconic Words on Historical Principles]. St. Petersburg, Institute of Foreign Languages/RHGA, $201 \mathrm{p}$.

Flaksman, M.A. (2017). Iconic Treadmill Hypothesis. The Reasons behind Continuous Onomatopoeic Coinage. In Dimensions of Iconicity: Iconicity in Language and Literature 15, ed. M. Bauer, A. Zirker, O. Fischer and Ch. Ljungberg. Amsterdam, John Benjamins 15-38. DOI: 10.1075/ill.15.02fl

Gazov-Ginzberg, A.M. (1965). Byl li iazyk zvukoizobrazitelen v svoikh istokakh? [Was the language iconic in its origin?]. Moscow, Nauka, 183 p.

Hinton, L., Nichols, J., Ohala, J.J. (eds.) (1994). Sound Symbolism. Cambridge, Cambridge University Press, $384 \mathrm{p}$.

Iconicity Atlas. An interactive multi-lingual comparative dictionary of iconic words (2018). Available at: http://www.iconicity-atlas.com/index.htm (accessed 16 May 2018).

Jakobson, R., Waugh, L.R. (1979). The Sound Shape of Language. London, Indiana University Press, $308 \mathrm{p}$.

Jespersen, O. (1933). Symbolic Value of the Vowel i. In Linguistica, 283-303.

Joseph, B.D. (1997). On the Iconic Elements in Etymological Investigation. In Diachronica, 4(1), 1-26.

Kankiia, N.D. (1988). Primarnaia motivirovannost' slova (na materiale angliiskogo i gruzinskogo iazykov) [The primary motivation of the word (in English and Georgian)]. Cand. Diss. Phil., Leningrad, University of Leningrad, $301 \mathrm{p}$.

Kuzmich, I.V. (1993). Zvukoizobrazitel'nost' $i$ amerikanskii sleng: fonosemanticheskii analiz. [Iconicity in American Slang: a Phonosemantic Analysis]. Cand. Diss. Phil., St. Petersburg, University of St. Petersburg, $249 \mathrm{p}$.

Lapkina, L.Z. (1979). Angliiskie i bashkirskie akusticheskie onomatopy [English and Bashkir Acoustic Onomatopes]. Cand. Diss. Phil., Leningrad, University of Leningrad, 222 p.

Liberman, A. (2010). Iconicity and Etymology. In Signergy: Iconicity in Language and Literature 9, ed. Conradie, J., Ronél J., Beukes, M., Fischer, O., Ljungberg, Ch. Amsterdam, Philadelphia, John Benjamins, 243-258.

Malkiel, Y. (1990). Diachronic Problems in Phonosymbolism. Amsterdam/Philadelphia, John Benjamins, $274 \mathrm{p}$.

Marchand, H. (1959). Phonetic Symbolism in English Word-Formation. In Indogermanische Forschungen, 64(2), 146-168; (3), 256-267.

Moreno Cabrera, J.C. (2017). Continuity and Change: On the iconicity of Ablaut Reduplication (AR). In Dimensions of Iconicity: Iconicity in Language and Literature 15, ed. M. Bauer, A. Zirker, O. Fischer and Ch. Ljungberg. Amsterdam, John Benjamins, 63-83. DOI: 10.1075/11l.15.04mor

Peirce, Ch.S. (2018). Peirce Edition Project. Available at: http://peirce.iupui.edu/ (accessed 6 May 2018).

Rozhanskii, F.I. (2011). Reduplikatsiia: opyt tipologicheskogo issledovaniia [Reduplication: Studies in Typoligy]. Moscow, Znak, $256 \mathrm{p}$.

Saussure, F. de (2006). Kurs obshchei lingvistiki [Course in General Linguistics]. Moscow, URSS, $256 \mathrm{p}$.

Shliakhova, S.S. (1991). Tipy i funktsii onomatopov v russkoi rechi [Types and Functions of Onomatopes in Russian Speech], Cand. Diss. Phil. Abstract, Leningrad, University of Leningrad, 24 p.

Slonitskaia, E.I. (1987). Zvukosimvolizm oboznachenii okruglogo (opyt tipologicheskogo issledovaniia) [Iconicity of Roundness (a Typological Comparison)]. Cand. Diss. Phil., Leningrad, University of Leningrad, $317 \mathrm{p}$.

Taylor, K.J. (2007). KA-BOOM! A Dictionary of Comic Book Words, Symbols and Onomatopoeia. Surrey BC, Mora Publications, $124 \mathrm{p}$.

Veldi, E.A. (1988). Anglo-estonskie paralleli v onomatopee [English-Estonian Parallels in Onomatopoeia]. Cand. Diss. Phil., Tartu, 388 p.

Voeltz, E., Kilian-Hatz, Ch. (eds.) (2001). Ideophones. Typological Studies in Language 44. Amsterdam, Philadelphia, John Benjamins, 433 p. 
Voronin, S.V. (1998). Angliiskie onomatopy: fonosemanticheskaia klassifikatsiia [English Onomatopes: a Phonosemantic Classification]. St. Petersburg, IFL Press, 196 p.

Voronin, S.V. (2005). Iconicity. Glottogenesis. Semiosis: Sundry Papers. St. Petersburg, St. Petersburg University Press, $146 \mathrm{p}$.

Voronin, S.V. (2006). Osnovy fonosemantiki [The Fundamentals of Phonosemantics]. Moscow, Lenand, $248 \mathrm{p}$.

Wescott, R. (1980). Sound and Sense. Linguistic Essays on Phonosemic Subjects. Lake Bluff, Jupiter Press, $392 \mathrm{p}$.

Written Sound. An Electronic Dictionary of Onomatopoeia (2018). Available at: http://www.writtensound.com/index.php (accessed 16 May 2018). 